\title{
Study on the comprehensive budget management of power supply enterprises in the county
}

\author{
Zheng ShunYuan ${ }^{1, a}$ and Yi Jing ${ }^{2, b^{*}}$ \\ ${ }^{1}$ School of Economics and Management, North China Electric Power University, Baoding, P.R.China \\ ${ }^{2}$ School of Economics and Management, North China Electric Power University, Beijing, P.R.China \\ a476595841@qq.com, byijing_bj@126.com
}

Keywords: Power supply enterprises in the county; Comprehensive budget management; Capital expenditure budget; Cost and expense budget; Improvement measures

\begin{abstract}
The present budget system plays an important role in strengthening the power enterprise management, ensuring the realization of the corporate strategic goal and improving corporate benefit steadily. However because of the economic and conditional limits, the comprehensive budget management system in county's power supply enterprises still have some urgent problems to be resolved. In this paper, through analyzing these problems, the author discusses the measures of improving comprehensive budget management system in county's power supply enterprises. Combined with the particularity of the county's power supply enterprise, established the capital expenditure budget management system and the cost and expense budget management system, in order to enrich the application mode of our budget management theory in the county power supply enterprise.
\end{abstract}

\section{Introduction}

The power industry, the pillar industry of China, has an irreplaceable important effect on the national economy ${ }^{[1]}$. After the reform of more than 20 years, Chinese power industry has made great progress. Comprehensive budget management is an effective management tool for the modern enterprises, whose role is to enhance the corporate effectiveness, county's power supply enterprise ${ }^{[2]}$. The present budget system plays an important role in strengthening the power enterprise management, ensuring the realization of the corporate strategic goal and improving corporate benefit steadily. However because of the economic and conditional limits, the comprehensive budget management system in county's power supply enterprises still have some urgent problems to be resolved ${ }^{[3]}$.

In this paper, the author first analyzed the existing problems of the comprehensive budget management system which can be concluded as five aspects ${ }^{[4]}$. That is the lack contact with strategic targets, the lack of sound organization system, the lack of capital expenditure budget, deficient cost and expense budget and the lack of scientific and effective evaluation system ${ }^{[5]}$. According to the problems analyzed, the author provided several measures to improve the comprehensive budget system in terms of each problem. The measures are divided into five aspects, that is, the restruction of the organization structure, establishment and disassembly of strategic objectives, the improvement of capital expenditure budget, the improvement of cost and expense budget and the establishment of evaluation system $^{[6]}$.

\section{Situation and problems of the current budget system}

Due to the limitation of economic and development situation, the county's electric power enterprises are under a relatively low development. The management mode is always the weak link, where a series of problems are still to be solved. There are basically five aspects of problems shown below ${ }^{[7]}$. 
Firstly, the contact is not close between the budget system and the strategic goals in the power supply enterprises, which means that the budget and the strategy is separate from each other. However, as is known, the comprehensive budget is an effective modern enterprise management tools in order to fulfill the strategic targets. The problem is definitely reducing the ability of the comprehensive budget management in fulfilling the strategic targets.

Secondly, despite the < detailed rules of budget management for the implementation of power supply enterprises $>$, the budget functions don't play their role very well owing to the lack of the practical operation. Budget management is involved in all aspects of the company and requires high coordination. However, in the current situation, some enterprises aren't able to set up budget management department and the budget planning department in the current budget system ${ }^{[8]}$. The fact is that the role of budget is divided into the finance department or the ministry department. Consequences are that the budget cannot play well a leadership role in the enterprises.

Thirdly, the power supply enterprises are lack of capital expenditure budget, whereas they put much emphasis on the cost and expense budget. It reflects that the power supply enterprises focus their attention on only the field of production and operation. The fact is that much failure of the enterprises is caused by an improper investment ${ }^{[9]}$. An unproved investment may lead to financial dilemma or even the operational failure.

Fourthly, the cost and expense budget in the power supply enterprises are disordered. The main budget method is increment budgeting which may hides the contradiction of budget management. The increment budgeting is in effect that acknowledge the all the past, however, the fact is always the opposite. The increment budgeting is sometimes Unscientific, which may discourage the stuff of the power supply enterprises. That is why the increment budgeting is difficult in promoting the company profit.

Lastly, the current budget management focuses mainly on the Budget Preparation instead of the Supervision and inspection on the practical performance ${ }^{[10]}$. The power supply enterprises are lack of a scientific and effective evaluation system, which affects the restraint and incentive role of budget management.

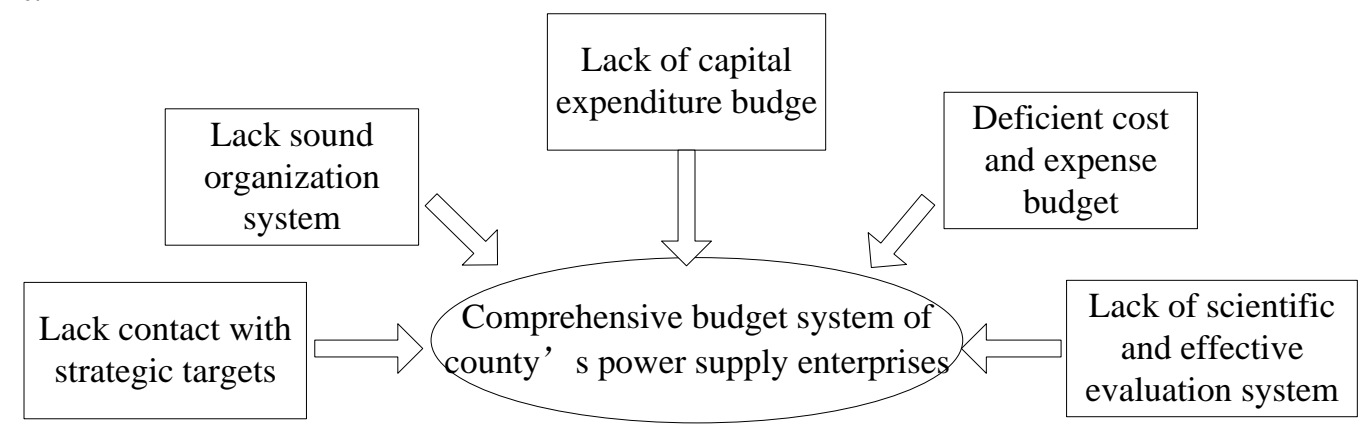

Figure. 1 Situation and problems of the current budget system

\section{Enhancement of the comprehensive budget management system}

(1) Restruction of the organization structure

The restruction of the organization structure is shown in Figure 2. 


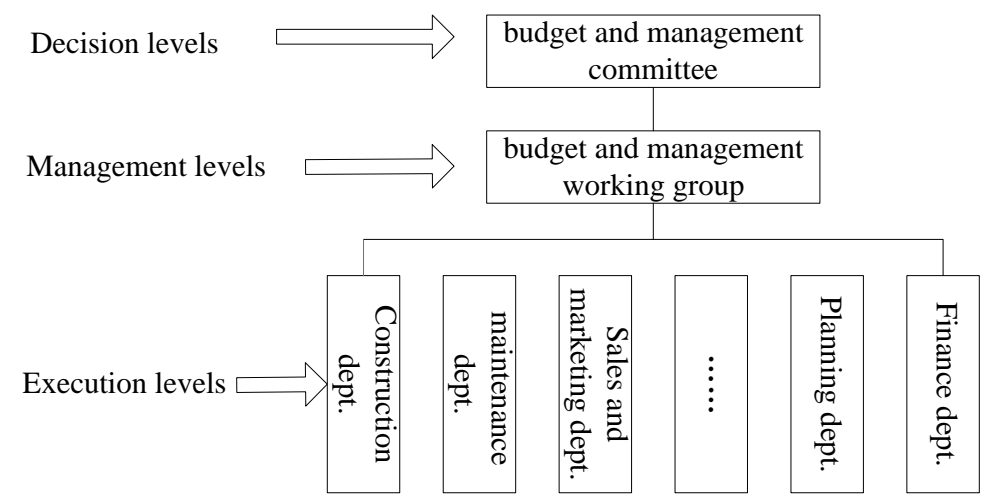

Figure. 2 restruction of the organization structure

(2) Establishment and disassembly of strategic objectives

The establishment and disassembly of strategic objectives are shown in Figure 3.

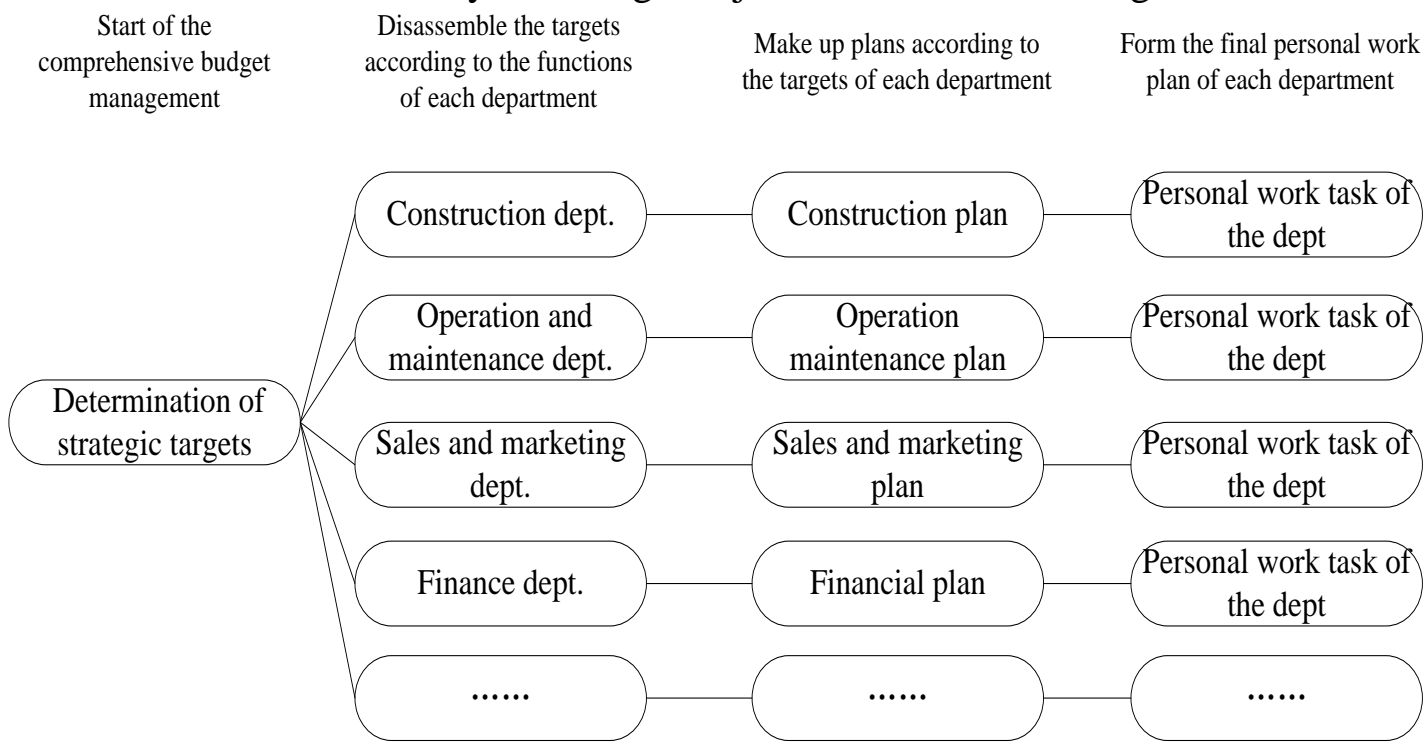

Figure. 3 establishment and disassembly of strategic objectives

(3) Capital expenditure budget

The capital expenditure budget is shown in Figure 4.

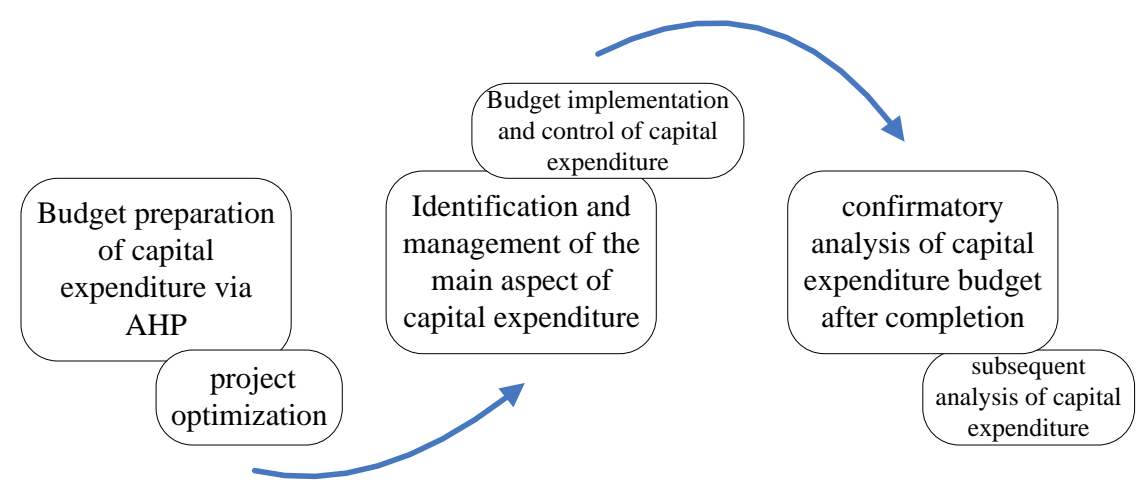

(4) Cost and expense budget

Figure. 4 capital expenditure budget

The cost and expense budget is shown in Figure 5. 


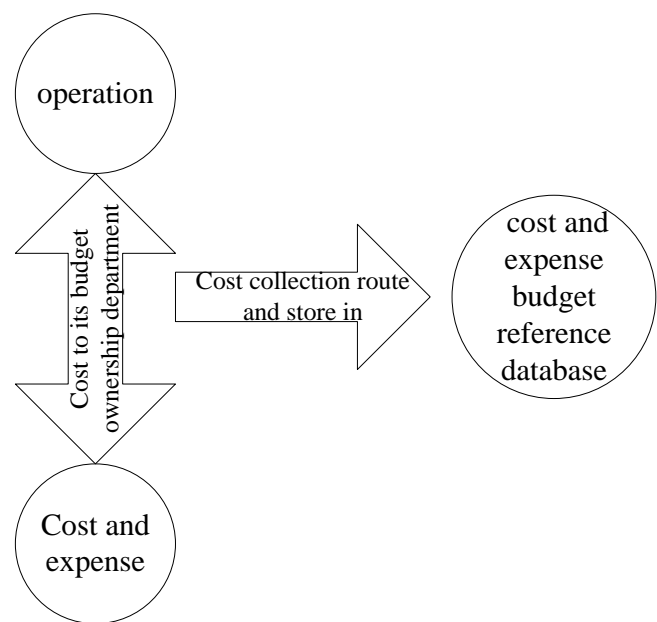

Figure. 5 cost and expense budget

(5) Evaluation system

The evaluation system is shown in Figure 6.

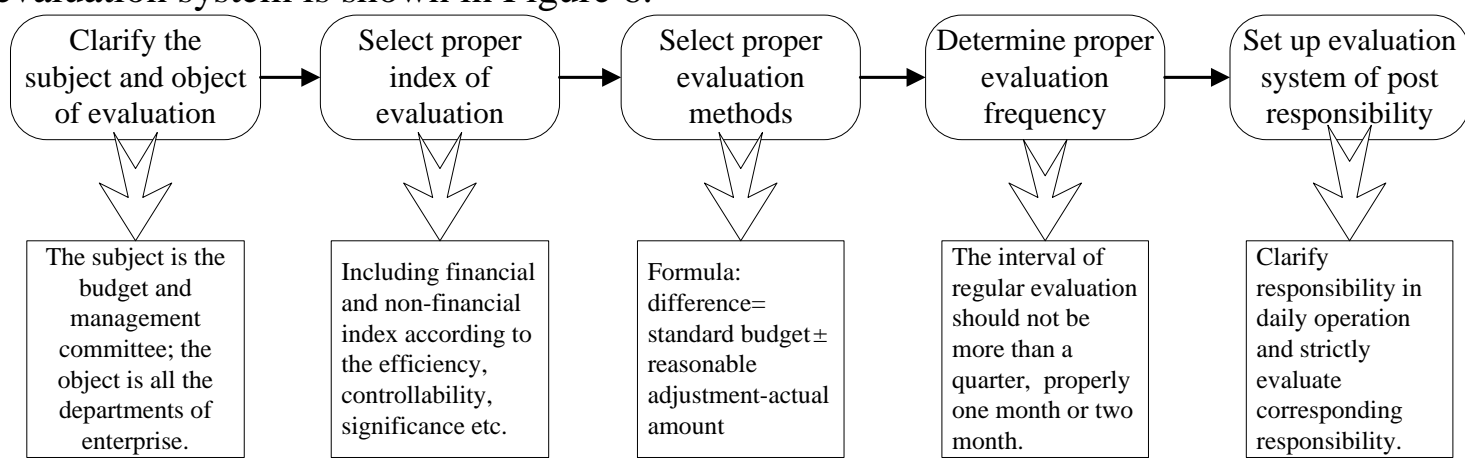

Figure. 6 evaluation system

\section{Summary}

The paper first analyzed the existing problems of the comprehensive budget management system which can be concluded as five aspects, which are that the lack contact with strategic targets, the lack of sound organization system, the lack of capital expenditure budget, deficient cost and expense budget and the lack of scientific and effective evaluation system. Then the author suggested several measures to improve the comprehensive budget system in terms of each problem, which can be divided into five aspects. That is the restruction of the organization structure, establishment and disassembly of strategic objectives, the improvement of capital expenditure budget, the improvement of cost and expense budget and the establishment of evaluation system.

\section{References}

[1] Jean-Bernard Le Gargasson, Benoît Mibulumukini, Bradford D. Gessner, Anaïs Colombini. Budget process bottlenecks for immunization financing in the Democratic Republic of the Congo (DRC). Vaccine, Volume 32， Issue 9， 19 February 2014， Pages 1036-1042

[2] L. Jones. Energy budgets for new construction. Energy and Buildings, Volume 2, Issue 2, April 1979, Pages 117-124

[3] WANG Jianjun. Study on the comprehensive budget of power enterprises.. Accountant, 2011.07.031 
[4] Clement K.W. Chow, Frank M. Song, Kit Pong Wong. Investment and the soft budget constraint in China. International Review of Economics \& Finance, Volume 19, Issue 2, April 2010, Pages 219-227

[5] L. Jones. Energy budgets for new construction. Energy and Buildings, Volume 2, Issue 2, April 1979, Pages 117-124

[6] QU Hang. The current research status of comprehensive budget management. Securities \& Futures of China, 2010(2):42-44

[7] SUN Zhenhua, WANG Qian. Literature review of the enterprise comprehensive budget management. Business Accounting, 2014, (17):66-68

[8] PAN Fei. Study on the Activity-based budgeting. Accounting Study. 2004.11.010

[9] LI Tianxia. Thinking on the accounting budget based on value chain. Value Enginerring, 2005.11.017

[10] Weitzman M L. The new soviet incentive model[M].Bell Journal of Economics， 1976，8:46-68 